\title{
Stimulation of Cholesteryl Ester Synthesis in Mouse Peritoneal Macrophages by Cholesterol-rich Very Low Density Lipoproteins from the Watanabe Heritable Hyperlipidemic Rabbit, an Animal Model of Familial Hypercholesterolemia
}

Toru Kita, Masayuki Yokode, Yoshio Watanabe, Shuh Narumiya, and Chuichi Kawai

Third Division, Departments of Internal Medicine and Medical Chemistry, Faculty of Medicine, Kyoto University, Kyoto 606, Japan; and Institute for Experimental Animals, Kobe University School of Medicine, Kobe, Japan

\begin{abstract}
Cholesterol-rich very low density lipoproteins (VLDL) from the homozygous Watanabe heritable hyperlipidemic (WHHL) rabbit induced marked cholesteryl ester accumulation in mouse peritoneal macrophages. This WHHL rabbit, an animal model of human familial hypercholesterolemia, has severe hypercholesterolemia, cutaneous xanthomas, and fulminant atherosclerosis due to the deficiency of the low density lipoprotein (LDL) receptor. When incubated with mouse peritoneal macrophages, the VLDL from WHHL rabbit (WHHL-VLDL) stimulated cholesteryl [ $\left.{ }^{14} \mathrm{C}\right]$ oleate synthesis 124 -fold more than did VLDL from the normal Japanese White rabbit (control-VLDL). The enhancement in cholesteryl ester synthesis and accumulation of WHHL-VLDL was due to the presence of a high affinity binding receptor site on the macrophage cell surface that mediated the uptake and lysosomal degradation of WHHL-VLDL.

Competition studies showed that the uptake and degradation of ${ }^{125}$ I-WHHL-VLDL was inhibited by unlabeled excess WHHL-VLDL and $\beta$-migrating VLDL ( $\beta$-VLDL), but not LDL. Furthermore, the degradation of WHHL-VLDL was not blocked by either fucoidin, polyinosinic acid, or polyguanylic acid, potent inhibitors of the acetylated (acetyl)-LDL binding site, or by acetyl-LDL. These results suggest that macrophages possess a high affinity receptor that recognizes the cholesterol-rich VLDL present in the plasma of the WHHL rabbit and that the receptor which mediates ingestion of WHHL-VLDL seems to be the same as that for $\beta$-VLDL and leads to cholesteryl ester deposition within macrophages.

Thus the uptake of the cholesterol-rich VLDL from the WHHL rabbit by macrophages in vivo may play a significant role in the pathogenesis of atherosclerosis in the WHHL rabbit.
\end{abstract}

\section{Introduction}

Similarities between arterial wall foam cells and tissue macrophages suggest that macrophages may be the progenitors of certain foam cells that are involved in atherogenesis (1-4). In a variety of experimental animals, such as rabbits, dogs, and monkeys, elevated plasma lipoprotein-bound cholesterol leads to the

Address reprint requests to Dr. Kawai, Third Division, Department of Internal Medicine, Faculty of Medicine, Kyoto University, 54 Kawaracho Shogoin, Sakyo-ku, Kyoto 606, Japan.

Received for publication 21 August 1985.

J. Clin. Invest.

(C) The American Society for Clinical Investigation, Inc. 0021-9738/86/05/1460/06 \$1.00

Volume 77, May 1986, 1460-1465 deposition of massive amounts of cholesteryl esters in macrophages throughout the body (5-8). An experimental system has recently been established by Goldstein and Brown (9) to investigate the mechanism of the deposition of the lipoprotein-derived cholesteryl esters in macrophages in vitro. Those macrophages have ingested large amounts of certain modified lipoproteins, such as acetylated low density lipoprotein (acetyl-LDL) ${ }^{1}$ (9), acetoacetylated LDL (10) and malondialdehyde-treated LDL (11) through the process of receptor-mediated endocytosis (9). In addition to the receptor that recognizes the acetyl-LDL, macrophages have another receptor that appears to be specific for beta-migrating very low density lipoprotein ( $\beta$-VLDL), a lipoprotein that accumulates in the blood of cholesterol-fed animals $(12,13)$. The studies of lipoprotein metabolism in macrophages were initiated to explain the paradoxical finding that even familial hypercholesterolemia $(\mathrm{FH})$ patients who have no LDL-receptor can accumulate lipoprotein-bound cholesteryl esters in macrophages (9). Although past studies revealed a variety of receptors that might mediate the macrophage uptake of modified lipoprotein cholesterol in these patients, such as acetyl-LDL and malondialdehyde-treated LDL (11), these receptors are specific only for chemically modified lipoproteins. At present it still remains unknown whether chemically modified lipoproteins exist in vivo. On the other hand, studies as to whether or not native lipoproteins in the FH patient are recognized in macrophages and form foam cells are nonexistent to date.

However, a new animal model of human familial hypercholesterolemia, known as Watanabe heritable hyperlipidemic (WHHL) rabbit (14), has recently become available. Homozygous WHHL rabbits resemble their human counterparts in having an accumulation of cholesterol-rich particles in the VLDL and intermediate density lipoprotein (IDL) density classes as well as in LDL on a low fat diet; extensive tissue cholesterol deposits (tender xanthomas); severe atherosclerosis; and a genetic defect in the LDL receptor in all tissues, including cultured skin fibroblasts, liver, and adrenal glands (15-19). Due to the recent availability of WHHL rabbits, we have been able to study the lipoprotein metabolism and to ascertain the accumulation of VLDL, IDL, and LDL in the plasma of this rabbit (20-23).

In this report we investigate whether native endogenous cholesterol-carrying lipoproteins, such as cholesterol-rich VLDL and IDL particles from WHHL rabbits, stimulate cholesteryl ester synthesis and storage in mouse peritoneal macrophages.

1. Abbreviations used in this paper: acetyl-LDL, acetylated very low density lipoprotein; $\beta$-VLDL, VLDL with $\beta$ mobility on electrophoresis; DME, Dulbecco's modified Eagle's medium; FCS, fetal calf serum; FH, familial hypercholesterolemia; IDL, intermediate density lipoprotein; Poly I, polyinosinic acid; Poly G, polyguanylic acid; VLDL, very low density lipoprotein; WHHL rabbit, Watanabe heritable hyperlipidemic rabbit. 


\section{Methods}

Animals and materials. Female DDY mice (25-30 g) and Japanese White male and female rabbits (3-3.5 kg) were purchased from Shimizu Laboratories (Kyoto, Japan). Homozygous WHHL rabbits were raised in Kyoto by mating heterozygous WHHL females with homozygous WHHL males. Mice were fed mouse laboratory chow (MF; Oriental Yeast Co. Ltd., Tokyo, Japan) and rabbits were fed rabbit laboratory chow (RC4; Oriental Yeast Co. Ltd.). [1 $\left.1{ }^{14} \mathrm{C}\right]$ oleic acid $(52.6 \mathrm{mCi} / \mathrm{mmol})$, [cholesteryl$\left.1,2,6,7-\left[{ }^{3} \mathrm{H}\right](N)\right]$-oleate $(79.8 \mathrm{Ci} / \mathrm{mmol})$ and $\mathrm{Na}^{125} \mathrm{I}(17.4 \mathrm{Ci} / \mathrm{mg})$ were obtained from New England Nuclear (Boston, MA). Bovine serum albumin (BSA) (cat. No. A4378), Oil Red $O$ stain, and chloroquine diphosphate were obtained from Sigma Chemical Co. (St. Louis, MO). Fetal calf serum (FCS), obtained from MA. Bioproduct Co. (Walkersville, MD), was heat-inactivated $\left(56^{\circ} \mathrm{C}, 30 \mathrm{~min}\right)$ before use. Dulbecco's modified Eagle's medium (DME) (cat. No. 05915) and Dulbecco's phosphatebuffered saline (cat. No. 05913) were purchased from Nissui Seiyaku Co., Ltd. (Tokyo, Japan). Plastic petri dishes were obtained from Falcon Labware, Division of Becton, Dickinson \& Co. (Oxnard, CA).

Fucoidin was obtained from ICN Nutritional Biochemicals (Cleveland, $\mathbf{O H}$ ).

Preparation of mouse macrophage monolayers. Peritoneal cells were harvested from unstimulated mice in phosphate-buffered saline as described by Edelson and Cohn $(24,25)$. The fluid from $20-40$ mice (3-6 $\times 10^{6}$ cells/mouse) was pooled and the cells were collected by centrifugation $\left(400 \mathrm{~g}, 10 \mathrm{~min}, 4^{\circ} \mathrm{C}\right)$ and washed once with $30 \mathrm{ml}$ of DME. The cells were resuspended in DME containing $10 \%$ (vol/vol) FCS, penicillin $(100 \mathrm{U} / \mathrm{ml})$, and streptomycin $(100 \mu \mathrm{g} / \mathrm{ml})$ at a final concentration of $2-3 \times 10^{6} \mathrm{cells} / \mathrm{ml}$. Aliquots $(1 \mathrm{ml})$. of this cell suspension were dispersed into plastic petri dishes $(35 \times 10 \mathrm{~mm})$ and then incubated in a humidified $\mathrm{CO}_{2}(5 \%)$ incubator at $37^{\circ} \mathrm{C}$. After $2 \mathrm{~h}$, each dish was washed three times with $2 \mathrm{ml}$ of DME without serum to remove nonadherent cells. After the monolayers were incubated for $18 \mathrm{~h}$ at $37^{\circ} \mathrm{C}$ in $1 \mathrm{ml}$ of DME containing 10\% FCS, the cells were washed with $2 \mathrm{ml}$ of DME and then used for the experiment. To initiate each experiment, $0.6 \mathrm{ml}$ or $1 \mathrm{ml}$ DME and serum lipoproteins were added to macrophage monolayers and incubated under conditions described above for the designated time periods.

Oil Red $O$ staining. Monolayers of macrophages were prepared on glass coverslips contained in petri dishes. After the indicated incubation, the coverslips were removed, fixed with $6 \%$ paraformaldehyde in $0.1 \mathrm{M}$ sodium phosphate ( $\mathrm{pH} \mathrm{7.3)}$ for $30 \mathrm{~min}$ at room temperature, and then fixed for $60 \mathrm{~min}$ in $2.5 \%$ potassium dichromate and $1 \%$ osmium tetroxide in water. The coverslips were then stained with Oil Red $O$ (26) and counterstained with Gill's double-strength hematoxylin for $10 \mathrm{~min}$.

Lipoproteins. Blood was obtained from normal 6-8 mo-old Japanese White and WHHL rabbits. VLDL $(d<1.006 \mathrm{~g} / \mathrm{ml})$, IDL $(d=1.006-$ $1.019 \mathrm{~g} / \mathrm{ml})$, and LDL $(d=1.019-1.063 \mathrm{~g} / \mathrm{ml})$ were isolated by ultracentrifugation from plasma prepared with anticoagulant EDTA (27). $\beta$-VLDL was isolated from Japanese White rabbits fed a 2\% cholesterol with $10 \%$ corn oil diet (28). All animals were fasted overnight before obtaining blood, and in some cases the plasma from two or more animals was pooled to obtain larger quantities of the $d<1.006 \mathrm{~g} / \mathrm{ml}$ fraction (VLDL) from normal Japanese White and WHHL rabbit. The VLDL was radioiodinated with iodine monochloride (29). More than $98 \%$ of the total ${ }^{125}$ I-radioactivity was precipitated by $10 \%$ TCA and less than $10 \%$ of the total ${ }^{125}$ I-radioactivity was extracted into chloroform-methanol.

Electrophoresis. Agarose gel electrophoresis of native lipoproteins was carried out as described (30).

Assays. The amounts of incorporation of $\left[{ }^{14} \mathrm{C}\right]$ oleate-albumin $(9,255$ $\mathrm{cpm} / \mathrm{nmol}$ ) into cellular cholesteryl $\left[{ }^{14} \mathrm{C}\right]$ oleate by cell monolayers were measured as described by Brown (25), except that serum was omitted from the incubation medium in most experiments (13). The proteolytic degradation of ${ }^{125}$ I-labeled lipoproteins by monolayers of mouse macrophages was measured by assaying the amount of ${ }^{125} \mathrm{I}$-labeled TCA soluble (noniodide) material formed by the cells and excreted into the culture medium (9). Corrections were made for the small amounts of acid-soluble
${ }^{125}$ I-labeled material ( $<0.01 \%$ of total radioactivity added) present in parallel incubations without cells. The protein content of lipoproteins and cells was determined by the method of Lowry et al. (31) with BSA as a standard. Each of the data represents an average of duplicate incubations.

\section{Results}

Light microscope studies of lipid accumulation in macrophages (foam cell formation). Mouse peritoneal macrophages were incubated in the presence of VLDL isolated from the plasma of either control Japanese White rabbits or WHHL rabbits for $3 \mathrm{~d}$ and then stained with neutral lipid stain Oil Red O. Fig. $1 A$ shows that cells incubated with WHHL-VLDL have numerous Oil Red O-positive droplets within the cytoplasm and that there are striking alterations in the morphology of these cells. In contrast, cells incubated with control-VLDL are virtually devoid of Oil Red O-positive droplets (Fig. $1 \mathrm{~B}$ ).

On agarose gel electrophoresis, WHHL-VLDL shows pre$\beta$-mobility, and this mobility is slower than that of control VLDL

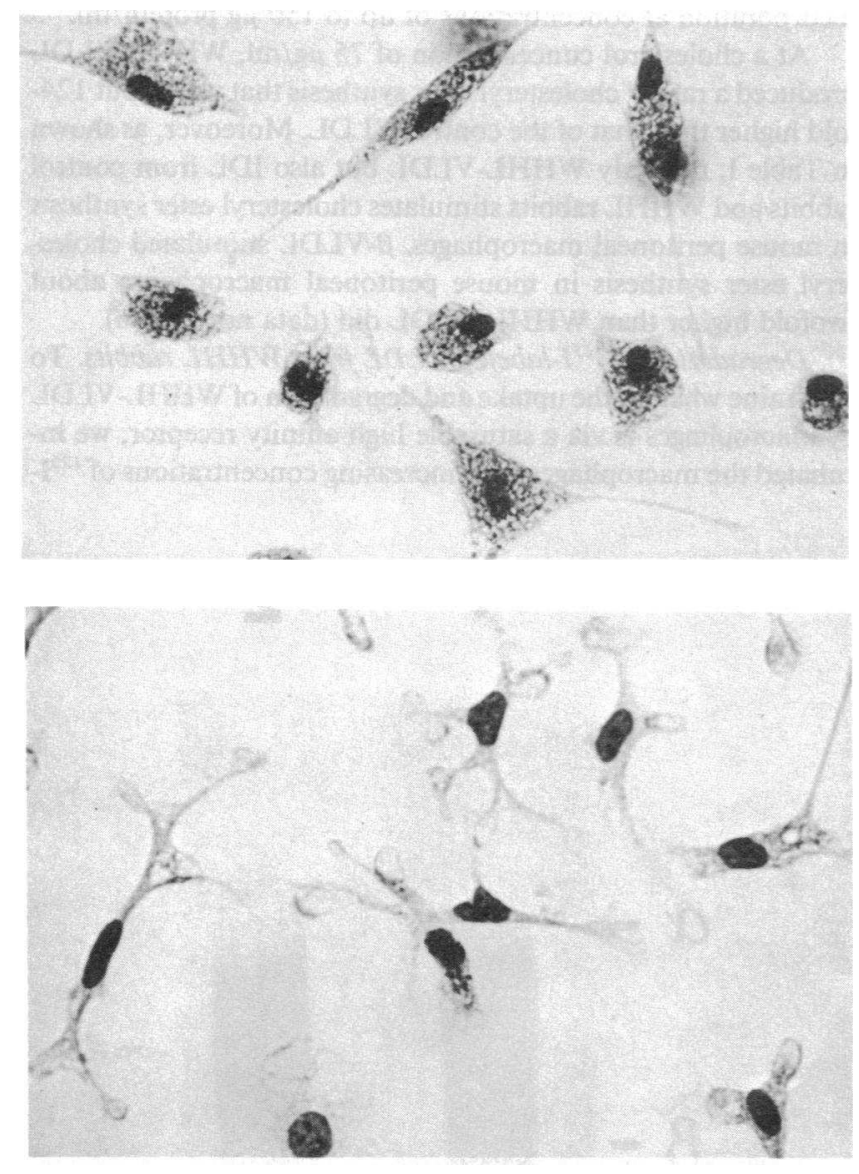

Figure 1. Light microscope appearance of macrophages incubated with WHHL-VLDL (top) and control-VLDL (bottom) and then stained with Oil Red $0.3 \times 10^{6}$ peritoneal cells were dispensed onto a glass coverslip contained within a 35-mm dish. On day 0, each dish received $1.0 \mathrm{ml}$ of DME containing $10 \%$ FCS and either $25 \mu \mathrm{g} / \mathrm{ml}$ of WHHL-VLDL (top) or $25 \mu \mathrm{g} / \mathrm{ml}$ of control-VLDL (bottom). The medium was replaced with fresh medium of identical composition on day 2. On day 3, the coverslips were removed and stained with Oil Red O (as described in Methods) $\times 400$. 
(Fig. 2). In 10\% sodium dodecyl sulfate gel electrophoretograms, a component with the mobility of apoprotein $\mathrm{E}$ was more prominent in WHHL-VLDL than in the control, and this result was the same as those described previously by Havel and Kita et al. (23).

The mass ratio of cholesterol to protein was increased in WHHL-VLDL as compared with the control (5.5 vs. 1.1). Therefore the cholesterol to protein ratio of WHHL-VLDL was about fivefold higher than that of control VLDL.

Stimulation of cholesteryl ester synthesis by VLDL from WHHL rabbits and control rabbits. To evaluate the ability of VLDL to stimulate cholesteryl ester accumulation in mouse peritoneal macrophages, we incubated macrophages with VLDL from either WHHL rabbits or control rabbits in the presence of $\left[{ }^{14} \mathrm{C}\right]$ oleate bound to $\mathrm{BSA}$ and measured the incorporation of $\left[{ }^{14} \mathrm{C}\right]$ oleate into the cellular cholesteryl esters.

As shown in Fig. 3, WHHL-VLDL markedly stimulated $\left[{ }^{14} \mathrm{C}\right]$ oleate incorporation into cellular cholesteryl ester in mouse peritoneal macrophages. The dose-response curve showed saturation kinetics with half-maximal stimulation occurring at 10 $20 \mu \mathrm{g}$ protein $/ \mathrm{ml}$.

On the contrary, control-VLDL failed to stimulate $\left[{ }^{14} \mathrm{C}\right]$ oleate incorporation at concentrations of up to $150 \mu \mathrm{g}$ protein $/ \mathrm{ml}$.

At a cholesterol concentration of $75 \mu \mathrm{g} / \mathrm{ml}$, WHHL-VLDL produced a rate of cholesteryl ester synthesis that was about 124fold higher than that of the control-VLDL. Moreover, as shown in Table I, not only WHHL-VLDL but also IDL from control rabbits and WHHL rabbits stimulates cholesteryl ester synthesis in mouse peritoneal macrophages. $\beta$-VLDL stimulated cholesteryl ester synthesis in mouse peritoneal macrophages about twofold higher than WHHL-VLDL did (data not shown).

Degradation of ${ }^{125}$ I-labeled VLDL from WHHL rabbits. To determine whether the uptake and degradation of WHHL-VLDL by macrophages is via a saturable high-affinity receptor, we incubated the macrophages with increasing concentrations of ${ }^{125} \mathrm{I}$ -

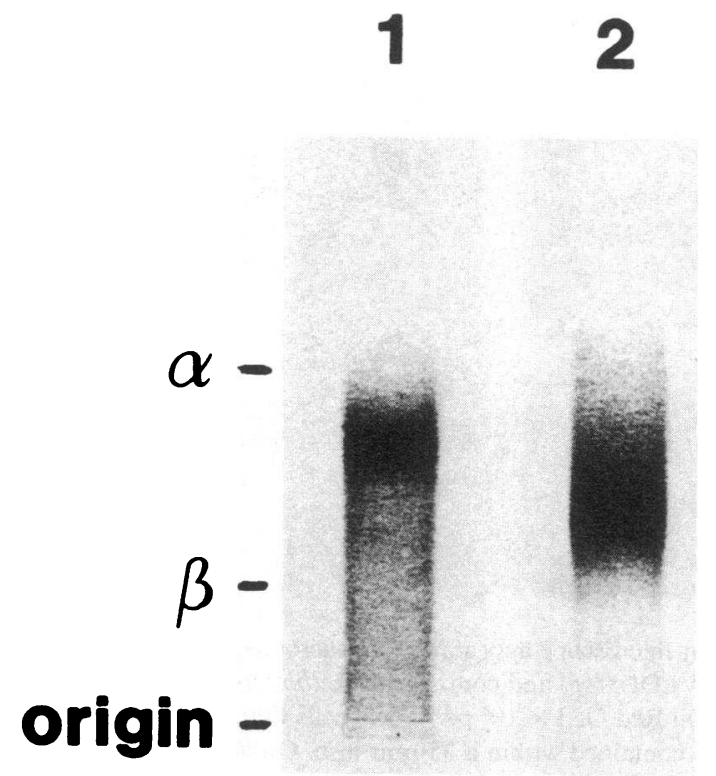

Figure 2. Agarose gel electrophoresis. Aliquots ( $25 \mu \mathrm{g}$ of protein) of VLDL from a control 24-h fasted rabbit (lane 1) and VLDL from a 24-h fasted WHHL rabbit (lane 2) were subjected to agarose gel electrophoresis and stained with Fat Red 7B.

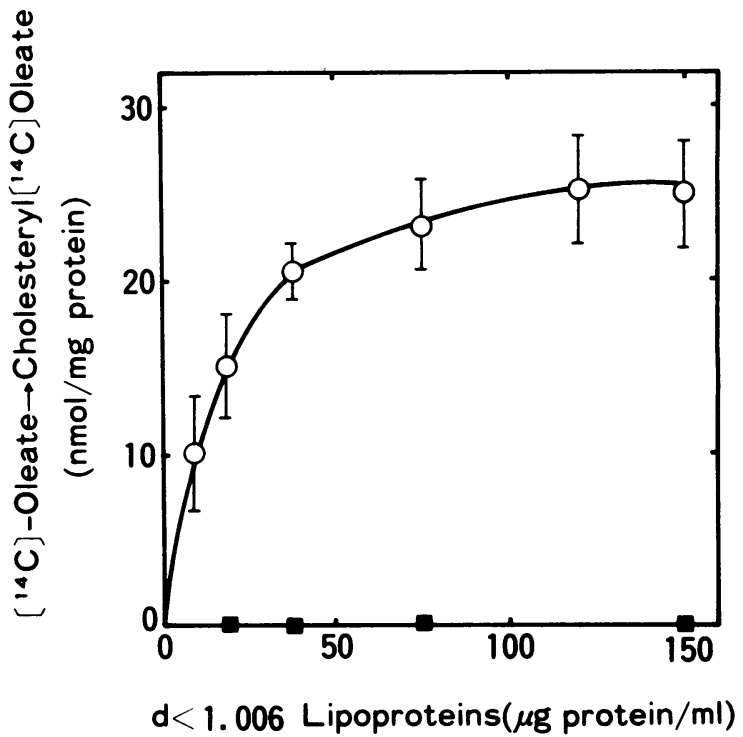

Figure 3. Cholesteryl ester formation in mouse macrophages incubated with varying concentrations of $d<1.006 \mathrm{~g} / \mathrm{ml}$ lipoproteins from control and WHHL rabbits. Each monolayer received $0.6 \mathrm{ml}$ of DME containing $0.2 \mathrm{mM}\left[{ }^{14} \mathrm{C}\right]$ oleate $-2.4 \mathrm{mg} / \mathrm{ml}$ albumin and the indicated concentration of $d<1.006 \mathrm{~g} / \mathrm{ml}$ lipoproteins obtained from one of the following animals: ( $($ ) control rabbits fed commercial rabbit chow; (0) WHHL-rabbits fed commercial rabbit chow. After incubation for $6 \mathrm{~h}$ at $37^{\circ} \mathrm{C}$, the cellular contents of cholesteryl $\left[{ }^{14} \mathrm{C}\right]$ oleate were determined. The content of cholesteryl $\left[{ }^{14} \mathrm{C}\right]$ oleate in cells incubated without $d<1.006 \mathrm{~g} / \mathrm{ml}$ lipoproteins was $0.17 \mathrm{nmol} / \mathrm{mg}$ protein. Each data point represents the mean \pm SD of values from three animals.

labeled WHHL-VLDL at $37^{\circ} \mathrm{C}$ for $5 \mathrm{~h}$. As Fig. 4 shows, uptake and degradation occurs in a dose-dependent manner with saturation kinetics ( $50 \%$ saturation at $10 \mu \mathrm{g}$ protein $/ \mathrm{ml}$ ).

To determine whether VLDL from WHHL rabbits was entering the macrophages by the classical LDL receptor (32), or by the receptor for chemically modified LDL, i.e., acetyl-LDL $(9-11)$, or by the receptor for $\beta$-VLDL $(12,13)$, or by its own receptor, the following experiments were done, as described in Fig. 5 and Table II.

Fig. 5 shows that control rabbit LDL at concentrations as high as $500 \mu \mathrm{g}$ protein/ml failed to compete with the ${ }^{125} \mathrm{I}-\mathrm{WHHL}$ VLDL for degradation. When LDL from WHHL rabbit was used for this experiment, we obtained the same results as with LDL from control rabbit.

In contrast, unlabeled WHHL-VLDL was effective in inhibiting the uptake and degradation of ${ }^{125} \mathrm{I}-$ WHHL-VLDL, with $50 \%$ inhibition occurring at a concentration of about $15 \mu \mathrm{g}$ protein $/ \mathrm{ml}$. The ability of unlabeled $\beta$-VLDL from cholesterol-fed rabbits to inhibit the degradation of ${ }^{125} \mathrm{I}-\mathrm{WHHL}-\mathrm{VLDL}$ was almost identical to that of WHHL-VLDL, with $50 \%$ inhibition at 5-10 $\mu \mathrm{g}$ protein $/ \mathrm{ml}$.

Moreover, as shown in Table II, the addition of negatively charged compounds, such as fucoidin, polyinosinic acid (Poly I) and polyguanylic acid (Poly G), previously shown to inhibit the binding of chemically modified LDL to the acetyl-LDL receptor (9), did not inhibit the stimulation of cholesteryl ester synthesis by WHHL-VLDL in mouse peritoneal macrophages.

To determine whether lysosomal hydrolysis of WHHLVLDL is required for the stimulation of cholesteryl $\left[{ }^{14} \mathrm{C}\right]$ oleate 
Table I. Stimulation of Cholesteryl Ester Formation in Mouse Peritoneal Macrophages by Lipoproteins from Control and WHHL Rabbits

\begin{tabular}{|c|c|c|c|}
\hline Source of lipoproteins & $\begin{array}{l}\text { Lipoprotein fraction } \\
\text { added to medium }\end{array}$ & {$\left[{ }^{14} \mathrm{C}\right]$ oleate-cholesteryl $\left[{ }^{14} \mathrm{C}\right]$ oleate } & $\begin{array}{l}\text { Mass ratio } \\
\text { cholesterol/protein }\end{array}$ \\
\hline & \multicolumn{3}{|c|}{ nmol/mg protein } \\
\hline & None & 0.18 & 0 \\
\hline \multirow[t]{3}{*}{ Control rabbit } & VLDL $(d<1.006)$ & 0.18 & 1.32 \\
\hline & IDL (1.006-1.019) & 9.20 & 0.89 \\
\hline & LDL (1.019-1.063) & 0.95 & 1.28 \\
\hline \multirow[t]{3}{*}{ WHHL rabbit } & VLDL $(d<1.006)$ & 22.4 & 5.56 \\
\hline & IDL (1.006-1.019) & 13.8 & 2.63 \\
\hline & LDL (1.019-1.063) & 0.93 & 1.11 \\
\hline
\end{tabular}

Each monolayer received $0.6 \mathrm{ml}$ of DME containing $0.2 \mathrm{mM}\left[{ }^{14} \mathrm{C}\right]$ oleate with $2.4 \mathrm{mg} / \mathrm{ml}$ albumin in the presence of $300 \mu \mathrm{g} / \mathrm{ml} \mathrm{cholesterol} \mathrm{of} \mathrm{the}$ indicated lipoprotein fraction. After incubation for $6 \mathrm{~h}$ at $37^{\circ} \mathrm{C}$, the cellular content of cholesteryl $\left[{ }^{14} \mathrm{C}\right]$ oleate was determined.

synthesis in macrophages, we tested the ability of chloroquine, an inhibitor of lysosomal enzyme function $(9,11)$, to block this stimulation.

As shown in Table II, chloroquine inhibited the stimulation of cholesteryl [ ${ }^{14} \mathrm{C}$ ]oleate synthesis by WHHL-VLDL at a concentration of $20 \mu \mathrm{M}$.

These results indicate that the uptake and degradation of WHHL-VLDL appear to be mediated via a specific high-affinity macrophage receptor for WHHL-VLDL that seems to be the same as that for $\beta$-VLDL, but is distinct from the receptors for modified LDL, such as acetyl-LDL or for LDL.

\section{Discussion}

In this current study, we have shown that the cholesterol-rich VLDL from WHHL rabbits was very potent in stimulating cho-

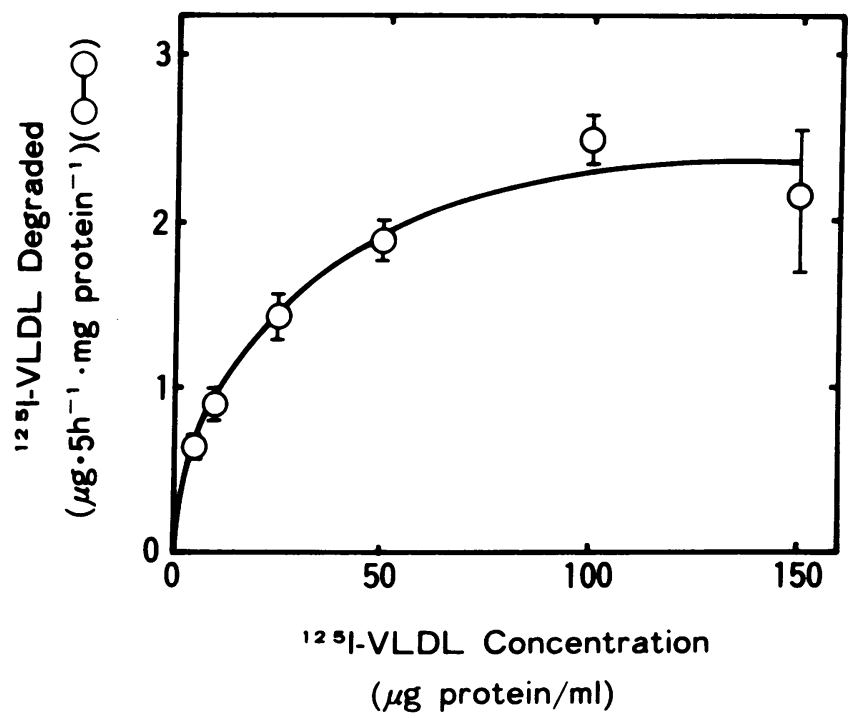

Figure 4. Degradation of ${ }^{125}$ I-labeled WHHL-VLDL by mouse peritoneal macrophages. Each monolayer received $1.0 \mathrm{ml}$ of DME and the indicated concentration of ${ }^{125}$ I-labeled WHHL-VLDL $(36 \mathrm{cpm} / \mathrm{ng}$ of protein). After incubation for $5 \mathrm{~h}$ at $37^{\circ} \mathrm{C}$, the amount of ${ }^{125} \mathrm{I}$-labeled acid-soluble material in the medium (o) was determined. Each data point represents the mean $\pm S D$ of values from three animals. lesteryl ester synthesis and storage in mouse peritoneal macrophages, and that this was not observed with control-VLDL (the VLDL from control Japanese White rabbits) (Fig. 1, Fig. 3). This ability of the cholesterol-rich VLDL from WHHL rabbits to produce cholesteryl ester storage in macrophages is dependent on the ability of WHHL-VLDL to bind to cell-surface-specific receptors and to be taken up by the cell. Although the specificity of the receptor site that binds WHHL-VLDL is not yet clear, this site appears to be the same as the $\beta$-VLDL receptor (Fig.

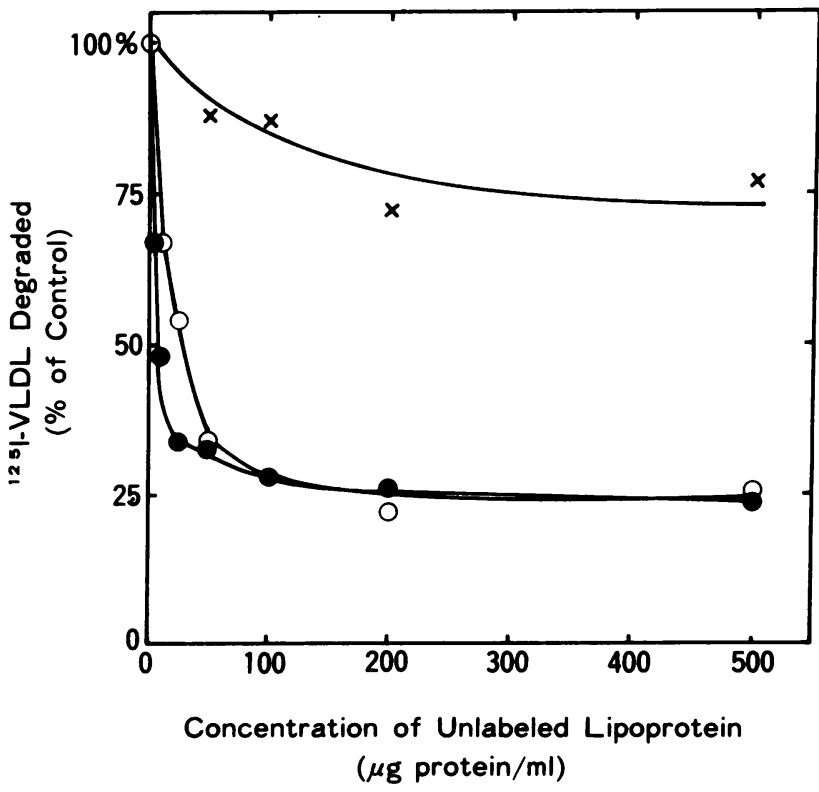

Figure 5. Ability of unlabeled rabbit $\beta$-VLDL, control rabbit LDL and WHHL-VLDL to inhibit the degradation of ${ }^{125} \mathrm{I}$-labeled WHHLVLDL by macrophages. Each monolayer received $1.0 \mathrm{ml}$ of DME containing $25 \mu \mathrm{g}$ protein/ml of ${ }^{125} \mathrm{I}$-labeled WHHL-VLDL $(89 \mathrm{cpm} / \mathrm{ng}$ of protein) and the indicated concentration of either unlabeled rabbit $\beta$-VLDL (๑), unlabeled control rabbit LDL $(x)$, or unlabeled WHHL VLDL (o). After incubation for $5 \mathrm{~h}$ at $37^{\circ} \mathrm{C}$, the amount of ${ }^{125} \mathrm{I}-\mathrm{la}-$ beled acid soluble material in the medium was determined. The $100 \%$ values for the degradation of the ${ }^{125} \mathrm{I}-\mathrm{WHHL}-\mathrm{VLDL}$ in the absence of competing lipoproteins were $1.26 \mu \mathrm{g}$ of degraded $5 \mathrm{~h}^{-1} \cdot \mathrm{mg}$ of protein $^{-1}$. Each point represents the mean of duplicate determinations. 
Table II. Stimulation of Cholesteryl Ester Synthesis in Mouse Peritoneal Macrophages by Lipoproteins from Control and WHHL Rabbits and Its Inhibition by Chloroquine, Fucoidin Polyinosinic Acid and Polyguanylic Acid

\begin{tabular}{|c|c|}
\hline Addition to medium & $\begin{array}{l}\text { Incorporation }\left[{ }^{14} \mathrm{C}\right] \text { ]leate } \\
\text { into cholesteryl }\left[{ }^{[4} \mathrm{C}\right] \text { oleate }\end{array}$ \\
\hline & nmol/mg protein \\
\hline None & 0.18 \\
\hline WHHL-VLDL ( $300 \mu \mathrm{g}$ cholesterol/ml alone) & 22.4 \\
\hline+ Chloroquine $(20 \mu \mathrm{M})$ & 0.19 \\
\hline+ Fucoidin $(100 \mu \mathrm{g} / \mathrm{ml})$ & 16.6 \\
\hline + Poly I $(30 \mu \mathrm{g} / \mathrm{ml})$ & 20.1 \\
\hline + Poly G $(30 \mu \mathrm{g} / \mathrm{ml})$ & 25.5 \\
\hline Control VLDL ( $300 \mu \mathrm{g}$ cholesterol/ml alone) & 0.18 \\
\hline
\end{tabular}

Monolayers of mouse peritoneal macrophages were prepared by the standard procedure described in Methods. Each 35-mm dish received $0.6 \mathrm{ml}$ of medium containing $0.2 \mathrm{mM}\left[{ }^{14} \mathrm{C}\right]$ oleate albumin $(9,255$ $\mathrm{cpm} / \mathrm{nmol}$ ) and the indicated addition. After incubation for $6 \mathrm{~h}$ at $37^{\circ} \mathrm{C}$, the amount of cholesteryl $\left[{ }^{14} \mathrm{C}\right]$ oleate formed by the cells was determined.

5). But it was distinct from the one responsible for the uptake of acetyl-LDL, because the degradation of VLDL from WHHL rabbit was not blocked by either fucoidin, Poly I, or Poly G, potent inhibitors of the acetyl-LDL binding site (Table II), or by acetyl-LDL itself (data not shown).

At present we know that WHHL-VLDL resembles VLDL remnants in several ways: enrichment in cholesteryl esters and in apoprotein $\mathrm{E}$, with little apoprotein $\mathrm{C}$ present (23), and reduced electrophoretic mobility on agarose gel electrophoresis (Fig. 2). But the distinctive nature of the component responsible for the uptake of WHHL-VLDL by macrophages has not yet been identified. Bersot et al. (33) indicated that the $\beta$-VLDL receptor recognition factors were apoproteins, but the specific apoprotein has not been identified (33).

The WHHL rabbit, an animal model of human FH, lacks cell-surface receptors for LDL, just as do FH patients (18). Therefore the clearance of VLDL, IDL, and LDL, all the endogenous lipoproteins that contain apoprotein B-100; is markedly delayed in WHHL rabbits $(18,20-22)$. Similar findings were made in studies of the turnover of ${ }^{125} \mathrm{I}-\mathrm{VLDL}$ in human FH (34). Nevertheless, the excess endogenous lipoprotein-bound cholesterol becomes deposited in nonparenchymal cells throughout the body, such as Kupffer cells and macrophages of the spleen, tendons, skin, and other organs, both in WHHL rabbit and FH patients $(19,35)$.

Extensive studies of lipoprotein metabolism in macrophages in the past several years began to explain the paradoxical finding as described above. Goldstein et al. showed that the uptake of lipoprotein-bound cholesterol in macrophages occurs via specific high-affinity receptors such as modified LDL receptor (9) and $\beta$-VLDL receptor $(12,13)$. Furthermore, Van Lenten et al. demonstrated that the $\beta$-VLDL receptor was present on macrophages from WHHL rabbits and from humans with the homozygous form of familial hypercholesterolemia $(36,37)$.

Studies of the WHHL rabbit showed that this rabbit has a striking abnormality in VLDL, IDL, and LDL metabolism (18,
23). Because it lacks the LDL receptor, VLDL is converted to IDL at a relatively normal rate. However, most IDL particles fail to enter the liver for catabolism, so IDL particles remain in the circulation where it is converted to $\operatorname{LDL}(18,22)$. On the other hand, in the normal rabbit, the vast majority of IDL particles disappear rapidly from the plasma because it binds to the LDL receptors on the surface of hepatic cells, due to the presence of apoprotein $\mathrm{E}$, which has a higher affinity for $\mathrm{LDL}$ receptors than apoprotein B-100 $(38,40)$. Table II showed that not only VLDL particles from the WHHL rabbit, but also IDL particles from control and WHHL rabbits can stimulate cholesteryl ester synthesis on macrophages. Remnant lipoproteins, including IDL, are proposed by Zilversmit to be the primary cause of atherosclerosis in cholesterol-fed animals (39). As mentioned above, IDL particles are not present in the plasma for a long time in normal rabbits, so even though IDL particles themselves stimulate cholesteryl ester synthesis on macrophages, IDL particles are not dangerous in atherosclerosis in the normal rabbit.

Once LDL receptors in the liver are reduced by taking cholesterol feeding $(28,40)$, or deficient because of the genetic defect, IDL particles are no longer taken up by the hepatic LDL receptor and remain in the plasma. Subsequently, they become dangerous as far as the formation of atherosclerosis is concerned.

At present, VLDL and IDL from the WHHL rabbit, and modified LDL, may play an important role for the pathogenesis of atherosclerosis in WHHL rabbits. We are now investigating which components of VLDL from the WHHL rabbit are recognized by the WHHL-VLDL macrophage receptor.

\section{Acknowledgments}

The authors wish to thank Miss Chiri Lanphere for editorial assistance and Miss Sachiko Shibano for typing the manuscript.

This work was supported by research grants from the Ministry of Education, Science, and Culture of Japan (No. 59570124); Kanae Foundation of Research for New Medicine; Mochida Memorial Foundation for Medical and Pharmaceutical Research; and Takeda Science Symposium Foundation.

\section{References}

1. Poole, J. C. F., and H. W. Florey. 1958. Changes in the endothelium of the aorta and the behavior of macrophages in experimental atheroma of rabbits. J. Pathol. Bacteriol. 75:245-252.

2. Fowler, S., H. Shio, and N. J. Haley. 1979. Characterization of lipid-laden aortic cells from cholesterol-fed rabbits. IV. Investigation of macrophage-like properties of aortic cell populations. Lab. Invest. 41: 372-378.

3. Schaffner, T., K. Taylor, E. J. Bantucci, K. Fischer-Dzoga, J. H. Beeson, S. Glagov, and R. Wissler. 1980. Arterial foam cells with distinctive immunomorphologic and histochemical features of macrophages. Am. J. Pathol. 100:57-80.

4. Steinberg, D. 1983. Lipoproteins and atherosclerosis: a look back and a look ahead. Arteriosclerosis. 3:283-301.

5. Mahley, R. W. 1978. Alterations in plasma lipoproteins induced by cholesterol feeding in animals including man. In Disturbances in Lipid and Lipoprotein Metabolism. J. M. Dietschy, A. M. Gotto, and J. A. Ontko, editors. American Physiological Society, Bethesda, MD. 181-197.

6. Mahley, R. W. 1970. Dietary fat, cholesterol, and accelerated atherosclerosis. Atheroscler. Rev. 5:1-34.

7. Wissler, R. W., and D. Vesselinovitch. 1968. Comparative pathogenetic patterns in atherosclerosis. Adv. Lipid Res. 6:181-206.

8. Fredrickson, D. S., J. L. Goldstein, and M. S. Brown. 1978. The 
familial hyperlipoproteinemias. In The Metabolic Basis of Inherited Disease. J. B. Stanbury, J. B. Wyngaarden, and D. S. Fredrickson, editors. McGraw-Hill Book Co., New York. 604-655.

9. Goldstein, J. L., Y. K. Ho, S. K. Basu, and M. S. Brown. 1979. Binding site on macrophages that mediates uptake and degradation of acetylated low density lipoprotein, producing massive cholesterol deposition. Proc. Natl. Acad. Sci. USA. 76:333-337.

10. Mahley, R. W., T. L. Innerarity, K. H. Weisgraber, and S. Y. Oh. 1979. Altered metabolism (in vivo and in vitro) of plasma lipoproteins after selective chemical modification of lysine residues of the apoproteins. J. Clin. Invest. 64:743-750.

11. Fogelman, A. M., I. Schechter, M. Hokom, J. S. Child, and P. A. Edwards. 1980. Malondialdehyde alteration of low density lipoprotein leads to cholesterol accumulation in human monocyte-macrophages. Proc. Natl. Acad. Sci. USA. 77:2214-2218.

12. Goldstein, J. L., Y. K. Ho, M. S. Brown, T. L. Innerarity, and R. W. Mahley. 1980. Cholesteryl ester accumulation in macrophages resulting from receptor-mediated uptake and degradation of hypercholesterolemic canine $\beta$-very low density lipoproteins. J. Biol. Chem. 255: 1839-1848.

13. Mahley, R. W., T. L. Innerarity, M. S. Brown, Y. K. Ho, and J. L. Goldstein. 1980. Cholesteryl ester synthesis in macrophages: stimulation by $\beta$-very low density lipoproteins from cholesterol-fed animals of several species. J. Lipid Res. 21:970-980.

14. Watanabe, Y. 1980. Serial inbreeding of rabbits with hereditary hyperlipidemia (WHHL-rabbit): incidence and development of atherosclerosis and xanthoma. Atherosclerosis. 36:261-268.

15. Kita, T., M. S. Brown, Y. Watanabe, and J. L. Goldstein. 1981. Deficiency of low density lipoprotein receptors in liver and adrenal gland of the WHHL rabbit, an animal model of familial hypercholesterolemia. Proc. Natl. Acad. Sci. USA. 78:2268-2272.

16. Tanzawa, K., T. Shimada, M. Kuroda, Y. Tsujita, M. Arai, and Y. Watanabe. 1980. WHHL-rabbit: a low density lipoprotein receptordeficient animal model for familial hypercholesterolemia. FEBS (Fed. Eur. Biochem. Soc.) Lett. 118:81-84.

17. Attie, A. D., R. C. Pittman, Y. Watanabe, and D. Steinberg. 1981. Low density lipoprotein receptor deficiency in cultured hepatocytes of the WHHL rabbit: further evidence of two pathways for catabolism of exogenous protein. J. Biol. Chem. 256:9789-9792.

18. Goldstein, J. L., T. Kita, and M. S. Brown. 1983. Defective lipoprotein receptors and atherosclerosis. Lessons from an animal counterpart of familial hypercholesterolemia. N. Engl. J. Med. 309:288-296.

19. Buja, L. M., T. Kita, J. L. Goldstein, Y. Watanabe, and M. S. Brown. 1983. Cellular pathology of progressive atherosclerosis in the WHHL rabbit. An animal model of familial hypercholesterolemia. $\mathbf{A r}$ teriosclerosis. 3:87-101.

20. Bilheimer, D. W., Y. Watanabe, and T. Kita. 1982. Impaired receptor-mediated catabolism of low density lipoprotein in the WHHL rabbit, an animal model of familial hypercholesterolemia. Proc. Natl. Acad. Sci. USA. 79:3305-3309.

21. Kita, T., J. L. Goldstein, M. S. Brown, Y. Watanabe, C. A. Hornick, and R. J. Havel. 1982. Hepatic uptake of chylomicron remnants in WHHL rabbits: a mechanism genetically distinct from the low density lipoprotein receptor. Proc. Natl. Acad. Sci. USA. 79:3623-3627.

22. Kita, T., M. S. Brown, D. W. Bilheimer, and J. L. Goldstein. 1982. Delayed clearance of very low density and intermediate density lipoproteins with enhanced conversion to low density lipoprotein in WHHL rabbits. Proc. Natl. Acad. Sci. USA. 79:5693-5697.

23. Havel, R. J., T. Kita, L. Kotite, J. P. Kane, R. L. Hamilton,
J. L. Goldstein, and M. S. Brown. 1982. Concentration and composition of lipoproteins in blood plasma of the WHHL rabbit: an animal model of human familial hypercholesterolemia. Arteriosclerosis. 2:467-474.

24. Edelson, P. J., and Z. A. Cohn. 1976. Purification and cultivation of monocytes and macrophages. In In Vitro Methods in Cell-Mediated and Tumor Immunity. B. R. Bloon and J. R. David, editors. Academic Press, New York. 333-340.

25. Brown, M. S., J. L. Goldstein, M. Krieger, Y. K. Ho, and R. G. W. Anderson. 1979. Reversible accumulation of cholesteryl esters in macrophages incubated with acetylated lipoproteins. J. Cell Biol. 82: 597-613.

26. Basu, S. K., R. G. W. Anderson, J. L. Goldstein, and M. S. Brown. 1977. Metabolism of cationized lipoproteins by human fibroblasts. Biochemical and morphologic correlations. J. Cell Biol. 74:119135.

27. Havel, R. J., H. Eder, and J. Bragdon. 1955. The distribution and chemical composition of ultracentrifugally separated lipoproteins in human serum. J. Clin. Invest. 34:1345-1353.

28. Kovanen, P. T., M. S. Brown, S. K. Basu, D. W. Bilheimer, and J. L. Goldstein. 1981. Saturations and suppression of hepatic lipoprotein receptors: a mechanism for the hypercholesterolemia of cholesterol-fed rabbits. Proc. Natl. Acad. Sci. USA. 78:1396-1400.

29. Bilheimer, D. W., S. Eisenberg, and R. I. Levy. 1972. The metabolism of very low density lipoproteins. I. Preliminary in vitro and in vivo observations. Biochim. Biophys. Acta. 260:212-221.

30. Nobel, R. P. 1968. Electrophoretic separation of plasma lipoproteins in agarose gel. J. Lipid Res. 9:693-700.

31. Lowry, O. H., N. J. Rosenbrough, A. L. Farr, and R. J. Randall. 1951. Protein measurement with the folin phenol reagent. J. Biol. Chem. 193:265-275.

32. Goldstein, J. L., and M. S. Brown. 1977. The low-density lipoprotein pathway and its relation to atherosclerosis. Annu. Rev. Biochem. 46:897-930.

33. Bersot, T. P., T. L. Innerarity, R. W. Mahley, and R. J. Havel. 1983. Cholesteryl ester accumulation in mouse peritoneal macrophages induced by $\beta$-migrating very low density lipoproteins from patients with atypical dysbetalipoproteinemia. J. Clin. Invest. 72:1024-1033.

34. Soutar, A. K., N. B. Myant, and G. R. Thompson. 1982. The metabolism of very low density and intermediate density lipoproteins in patients with familial hypercholesterolaemia. Atherosclerosis. 43:217231.

35. Buja, L. M., P. T. Kovanen, and D. W. Bilheimer. 1979. Cellular pathology of homozygous familial hypercholesterolemia. Am. J. Pathol. 97:327-357.

36. Van Lenten, B. J., A. M. Fogelman, M. M. Hokom, L. Benson, M. E. Haberland, and P. A. Edwards. 1983. Regulation of the uptake and degradation of $\beta$-very low density lipoprotein in human monocyte macrophages. J. Biol. Chem. 258:5151-5157.

37. Van Lenten, B. J., A. M. Fogelman, R. L. Jackson, S. Shapiro, M. E. Haberland, and P. A. Edwards. 1985. Receptor-mediated uptake of remnant lipoproteins by cholesterol-loaded human monocyte macrophages. J. Biol. Chem. 260:8783-8788.

38. Brown, M. S., P. T. Kovanen, and J. L. Goldstein. 1981. Regulation of plasma cholesterol by lipoprotein receptors. Science (Wash. DC). 212:628-635.

39. Zilversmit, D. B. 1979. Atherogenesis: a postprandial phenomenon. Circulation. 60:473-485.

40. Mahley, R. W., and T. L. Innerarity. 1983. Lipoprotein receptors and cholesterol homeostasis. Biochim. Biophys. Acta. 737:197-222. 